\title{
Pengembangan Bahan Ajar Kimia Bahan Makanan Berbasis Web
}

\author{
Nopriawan Berkat Asi \\ Program Studi Pendidikan Kimia, FKIP, Universitas Palangka Raya, Indonesia \\ Email: nopriawanb@gmail.com
}

\begin{abstract}
Abstrak. Kimia bahan makanan adalah salah satu mata kuliah pilihan di Program Studi Pendidikan Kimia FKIP Universitas Palangka Raya. Pengembangan bahan ajar kimia bahan makanan berbasis web sebagai upaya memanfaatkan fasilitas komputer dan internet yang tersedia. Salah satu kelebihan bahan ajar berbasis web adalah memberi kemudahan bagi mahasiswa mengakses kembali bahan ajar setelah pembelajaran di kelas. Pemanfaatan teknologi komputer dan internet sebagai media pengembangan bahan ajar berbasis web di Program Studi Pendidikan Kimia FKIP Universitas Palangka Raya diharapkan dapat meningktakan kualitas pembelajaran. Bagi dosen dan mahasiswa dapat memberikan kemudahan dalam pengarsipan bahan ajar, kemudahan akses membuka arsip bahan ajar, kemudahan dalam melakukan perbaikan bahan ajar dan kemudahan dalam pembaharuan bahan ajar. Metode pengembangan bahan ajar kimia bahan makanan berbasis web yang digunakan adalah metode penelitian dan pengembangan pendidikan (Educational Research and Development) yang disingkat dengan R\&D. Gall et al. (2003) menyatakan R\&D adalah suatu proses yang digunakan untuk mengembangkan dan memvalidasi produk-produk pendidikan. Pengembangan ini menggunakan metode penelitian dan pengembangan model 3D, yaitu Define, Design, dan Develop, modifikasi model 4D Thiagarajan. Pada penelitian dilakukan uji coba skala terbatas. Bahan ajar kimia bahan makanan berbasis web berupa website pembelajaran dengan alamat www.kimia-kesehatan.blogspot.co.id layak digunakan sebagai media bahan ajar di Program Studi Pendidikan Kimia FKIP Universitas Palangka Raya.
\end{abstract}

Kata kunci: pengembangan, bahan ajar, berbasis web

\section{PENDAHULUAN}

Masyarakat Indonesia dewasa ini hidup dalam era teknologi informasi dan komunikasi yang serba cepat. Perkembangan teknologi informasi dan komunikasi (TIK) telah mengubah berbagai aspek kehidupan masyarakat, tak terkecuali dalam bidang pendidikan. Dalam era teknologi informasi dan komunikasi, masyarakat telah mengenal istilah e-banking untuk penerapan TIK dalam perbankan, $e$ commerce untuk penerapan TIK dalam perdagangan, dan lain-lain. Termasuk kita telah mengenal pula istilah e-learning sebagai bentuk penerapan TIK dalam pendidikan khususnya untuk tujuan pembelajaran. Tantangan pendidikan abad 21 adalah membangun masyarakat berpengetahuan (knowledge-based society). Untuk membangun hal tersebut, teknologi komputer dan internet memainkan peran yang sangat penting (Nopriawan, 2016).

Bahan ajar atau materi pelajaran merupakan media untuk mencapai tujuan pengajaran. Bahan ajar merupakan materi yang terus berkembang secara dinamis seiring dengan kemajuan dan tuntutan perkembangan masyarakat. Bahan ajar yang diterima peserta didik harus mampu merespons setiap perubahan dan mengantisipasi setiap perkembangan yang akan terjadi di masa depan. Bahan ajar merupakan unsur penting yang ada di dalam kegiatan belajar mengajar, karena 
bahan ajar tersebut yang diupayakan untuk dikuasai oleh peserta didik. Dengan demikian, bahan ajar merupakan komponen yang tidak dapat diabaikan dalam pengajaran, sebab bahan ajar merupakan inti dalam proses belajar mengajar.

Menurut Traxler (2010), dewasa ini teknologi komputer dan perangkat seluler didukung oleh teknologi internet yang makin maju. Banyak pendidik menganjurkan, mempromosikan dan mendorong impian tentang pentingnya lembaga pendidikan bertanggung jawab atas penyediaan, pemerataan, akses, partisipasi dan standar layanan pendidikan berbasis teknologi komputer dan perangkat seluler. Lembaga pendidikan secara tradisional menyediakan dan mengendalikan teknologi untuk belajar tetapi sekarang sebagian besar peserta didik memperoleh teknologi pribadi mereka sendiri untuk pembelajaran sehingga institusi pendidikan ditantang untuk mengikuti. Hal ini memungkinkan peserta didik untuk memproduksi, menyimpan, mengirimkan dan mengkonsumsi informasi, gambar dan gagasan mereka sendiri.

Mahasiswa Program Studi Pendidikan Kimia FKIP Universitas Palangka Raya dapat memanfaatkan askses internet seperti @wifi.id, jaringan internet telkomsel 3G/4G, dan yang lainnya untuk mengakses bahan ajar berbasis web. Salah satu kelebihan bahan ajar berbasis web yang tentunya didukung teknologi komputer dan internet adalah memberi kemudahan bagi mahasiswa mengakses kembali bahan ajar setelah pembelajaran di kelas.

Oleh karena itu, berkaitan dengan upaya pengembangan bahan ajar kimia bahan makanan Program Studi Pendidikan Kimia FKIP Universitas Palangka Raya perlu dilakukan penelitian dan pengembangan. Bahan ajar berbasis web merupakan salah satu faktor penting untuk meningkatkan kualitas pendidikan dan pengajaran di lingkungan Universitas Palangka Raya.

\section{METODE}

Penelitian dilakukan menggunakan metode penelitian dan pengembangan

1. Model dan desain pengembangan produk

a. Model Produk

Model produk pengembangan ini berupa bahan ajar kimia bahan makanan berbasis web yang harus didukung teknologi komputer atau perangkat seluler yang terhubung internet.

b. Model pengembangan produk

Model pengembangan produk berupa model prosedural. Model prosedural yaitu model yang bersifat deskriptif, menggariskan langkah-langkah atau prosedur yang harus diikuti untuk menghasilkan produk berupa bahan ajar kimia bahan makanan berbasis web.

2. Metode pengembangan produk

Metode pengembangan produk bahan ajar kimia bahan makanan berbasis web yang digunakan adalah metode penelitian dan pengembangan pendidikan (Educational Research and Development) yang disingkat dengan R\&D. Gall et al. (2003) menyatakan R\&D adalah suatu proses yang digunakan untuk mengembangkan dan memvalidasi produk-produk pendidikan. Pengembangan ini menggunakan metode penelitian dan pengembangan model 3D, yaitu Define, Design, dan Develop, modifikasi model 4D Thiagarajan. Kegiatan pengembangan ditunjukkan pada Gambar 3.1. 
Tahap define adalah kegiatan mengumpulkan berbagai informasi yang diperlukan (needs assessment). Tahap design adalah kegiatan merancang produk awal atau draf produk awal. Tahap develop adalah kegiatan mengembangkan produk awal menjadi produk akhir. Pengembangan produk bahan ajar kimia bahan makanan berbasis web dilakukan melalui tiga tahap tersebut.

Aspek-aspek yang dinilai diadopsi dari (Sukarna, 2016) yaitu aspek materi dan soal, kebahasaan, keterlaksanaan, tampilan audio visual, rekayasa perangkat lunak.

3. Spesifikasi Produk Yang Dikembangkan

a. Spesifikasi produk yang dikembangkan pada penelitian ini mencakup antara lain:

b. Produk media pembelajaran dikembangkan menggunakan web log (blog)

c. Produk berbasis web yang didukung komputer dan seluler dapat diakses offline dan online.

d. Fitur yang disediakan dalam media pembelajaran berbasis web meliputi:

1) Materi pelajaran/bahan ajar dilengkapi video, animasi dan gambar.

2) Soal evaluasi.

\begin{tabular}{|l|l|}
\hline Define & $\begin{array}{l}\text { - Mengumpulkan informasi bahan ajar } \\
\text { - Mengumpulkan informasi web }\end{array}$ \\
\hline Design & $\begin{array}{l}\text { - Draft awal bahan ajar } \\
\text { Develop }\end{array}$ \\
\hline & - Pengembal web coba produk
\end{tabular}

Gambar 1. Desain Pengembangan Bahan Ajar Kimia Bahan Makanan Berbasis Web

\section{HASIL DAN PEMBAHASAN}

A. Hasil Pengembangan

1. Tahap Define

Informasi yang dikumpulkan pada tahap ini meliputi materi ajar, soal-soal evaluasi dan panduan (pengembangan dan penggunaan web). Bahan ajar kimia bahan makanan dikembangkan berdasarkan rujukan dari berbagai sumber. Panduan pengembangan dan penggunaan blog telah disusun oleh Nopriawan Berkat Asi (2017) dengan alamat web: https://caramembuatmedia.blogspot.co.id/.

2. Tahap Design

Blog yaitu singkatan dari web log yang merupakan bentuk dari aplikasi web yang dapat berbentuk tulisan-tulisan (yang dimuat sebagai posting) pada sebuah halaman web. Tulisan-tulisan atau posting dalam blog yang dihasilkan pada pengembangan ini dimuat dalam urutan terbalik (isi terbaru dahulu sebelum diikuti isi yang lebih lama), meskipun kedepannya tidak selamanya demikian karena bisa disetting oleh admin blog.

Pengembangan bahan ajar kimia bahan makanan berbasis web memanfaatkan salah satu penyedia blog gratis yaitu blogspot.com atau blogspot.co.id khusus 
untuk wilayah Indonesia. Selain itu terdapat juga wordpress.com yang juga gratis. Keduanya memiliki perbedaan, tetapi sama mudahnya jika telah menguasainya. Bagi yang baru belajar membuat blog sebaiknya pilih salah satu saja dahulu untuk dipelajari dan dikuasai.

Pada pengembangan ini digunakan blogspot.co.id sehingga pengguna harus memiliki surel atau email dengan alamat @ gmail.com, jika belum memiliki email pengguna harus membuatnya terlebih dahulu. Langkah-langkah membuat email dapat dilihat di alamat https://caramembuatmedia.blogspot.co.id/2017/01/caramembuat-email-gmailcom.html. Membuat email tidak sulit, pengguna hanya perlu waktu 1-2 menit, jika koneksi internet stabil dan cepat.

Pengguna harus selesai membuat email, kemudian siap untuk membuat alamat web di blogspot.co.id. Membuat alamat blog juga tidak sulit, hanya perlu waktu 2-5 menit. Langkah-langkah membuat alamat blog dapat dilihat di alamat https://caramembuatmedia.blogspot.co.id/2017/01/cara-membuat-

blogspotcom.html.

Langkah selanjutnya adalah yang agak rumit dan agak sulit, tetapi jika sudah terbiasa menjadi mudah untuk dilakukan. Pengguna harus paham dengan yang namanya html, edit html, tetapi tidak perlu kuatir untuk pemula karena dapat belajar menggunakan bantuan mesin pencari google.co.id. Pengguna dapat menggunakan secara langsung aplikasi atau kode yang sudah tersedia. Jadi pengguna pemula tidak perlu repot belajar bahasa program yang rumit, dan sulit.

Pada dashboard blogger terdapat menu-menu yang dapat diatur. Sebaiknya pengguna pemula pelajari dan pahami dahulu setiap menu yang ada di dashboard blogger tersebut. Penjelasan menu dashboard blogger dapat dilihat di https://caramembuatmedia.blogspot.co.id/2017/01/cara-mendesain-blog-agarcantik-dan.html.

Jika pengguna (admin blog) ingin mengubah template dapat dilakukan pada menu template, pilih template yang sesuai keinginan. Namun ada cara sederhana untuk memodifikasi template. Terlebih dahulu unduh template yang sesuai dengan tujuan penggunaan. Beberapa template yang sudah tersedia dapat diperoleh di alamat https://caramembuatmedia.blogspot.co.id/2017/01/template-blog-yangcantik-dan-menarik.html.

Pada menu template terdapat menu pilihan "backup/restore". Pengguna dapat mulai mengubah template menggunakan template yang telah diunduh. Langkahlangkah mengubah template dapat dilihat di alamat https://caramembuatmedia.blogspot.co.id/2017/01/cara-mengatur-atau-mengubahtemplate.html.

3. Tahap Develop

Produk awal bahan ajar kimia bahan makanan berbasis web hasil pengembangan menggunakan media blog berisi materi kimia bahan makanan soal-soal evaluasi. Materi ajar dapat diunduh (dikenakan biaya sesuai tarif provider) kemudian dapat dilihat secara offline (tidak dikenakan biaya). Materi ajar yang telah diunduh dapat dicopy atau disalin ke perangakat komputer atau seluler yang lain.

Materi ajar dapat diakses secara online dimana saja dan kapan saja oleh mahasiswa menggunakan perangkat komputer ataupun seluler pada jangkauan internet yang disediakan oleh provider. Bahan ajar kimia bahan makanan berbasis web ini memberikan banyak kemudahan bagi mahasiswa dan dosen dalam hal 
akses. Namun, akses terbatas hanya bagi pengguna perangkat komputer atau perangkat seluler yang terkoneksi internet. Materi produk awal dapat dilihat di alamat https://kimia-kesehatan.blogspot.co.id/

Soal-soal evaluasi diambil dari soal-soal tes yang telah dikembangkan dan digunakan dalam perkuliahan tahun-tahun sebelumnya. Soal-soal dalam bentuk pilihan ganda. Soal-soal ditampilkan pada laman blog menggunakan aplikasi google form. Soal evaluasi dapat digunakan secara online. Mahasiswa harus memiliki alamat surel (email) @gamail.com agar dapat mengakses laman jawaban. Soal-soal evaluasi dilengkapi kunci jawaban (langsung memberi umpan balik kepada mahasiswa), sehingga mahasiswa dapat mengetahui jawabannya yang salah atau benar. Mahasiswa dapat mengetahui persentase pemahamannya atau hasil evaluasi secara langsung setelah menyelesaikan seluruh soal evaluasi.

\section{B. Hasil Uji Coba}

Penilaian oleh ahli media dan ahli materi tidak dilakukan, karena peneliti sekaligus sebagai ahli media dan ahli materi. Penilaian bahan ajar kimia bahan makanan oleh teman sejawat yaitu dosen kimia. Hasil penilaian oleh teman sejawat menunjukkan bahwa produk awal bahan ajar kimia bahan makanan berbasis web layak digunakan, sehingga dapat dilanjutkan ketahap uji coba skala terbatas.

Gambar 2 menunjukkan hasil penilaian teman sejawat. Aspek 1 adalah rekayasa perangkat lunak. Aspek 2 adalah desain pembelajaran. Aspek 3 adalah komunikasi audio dan visual. Semua aspek memiliki nilai rata-rata 4. Hasil penilaian oleh teman sejawat menunjukkan bahwa produk awal bahan ajar kimia bahan makanan berbasis web layak digunakan, sehingga dapat dilanjutkan ketahap uji coba skala terbatas.

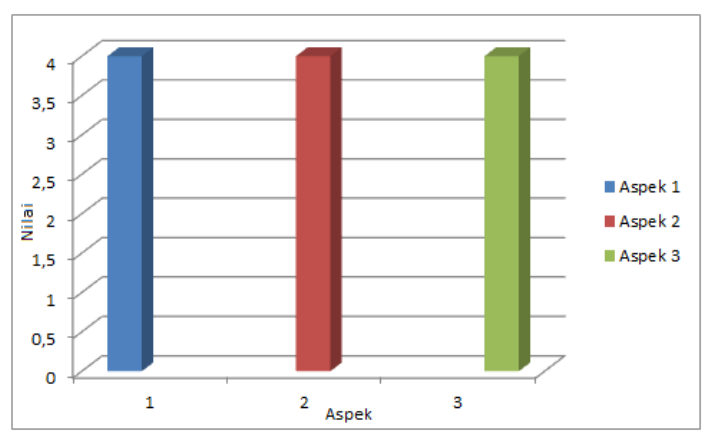

\section{Gambar 2. Hasil Penilaian Teman Sejawat}

Uji coba skala terbatas dilakukan di Program Studi Pendidikan Kimia Universitas Palangka Raya. Tujuannya untuk mengetahui respon mahasiswa terhadap media bahan ajar kimia bahan makanan berbasis web. Respon mahasiswa ditunjukkan pada Gambar 3. Respon 1 menyatakan efektif dan efisien. Respon 2 menyatakan handal. Respon 3 menyatakan mudah digunakan dan dioperasikan. Respon 4 menyatakan mudah dijalankan di perangkat komputer maupun seluler. Respon 5 menyatakan mudah diakses offline maupun online. Respon 6 menyatakan tujuan pembelajaran jelas. Respon 7 menyatakan materi ajar mudah dipahami. Respon 8 menyatakan bahwa uraian, pembahasan, contoh, latihan yang diberikan jelas. Respon 9 menyatakan senang belajar menggunakan bahan ajar versi digital. Respon 10 menyatakan bahan ajar versi digital menarik 
dan memikat. Skor 1 menyatakan tidak. Skor 2 menyatakan kurang. Skor 3 menyatakan cukup. Skor 4 menyatakan sangat.

Uji coba skala diperluas belum dilakukan, karena keterbatasan waktu dan dana. Uji coba skala diperluas akan dilaksanakan kemudian karena memerlukan waktu yang lebih lama dan mahasiswa yang lebih banyak.

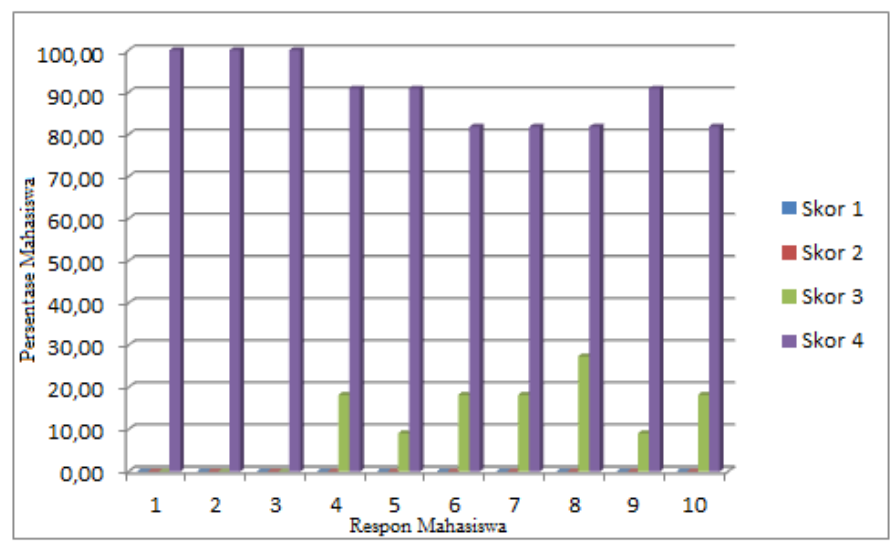

Gambar 3. Respon mahasiswa

\section{Pembahasan}

Penelitian ini merupakan jenis penelitian dan pengembangan bahan ajar. Hasil penelitian dan pengembangan ini adalah produk media pembelajaran berbasis web yang tentu harus didukung komputer dan internet. Materi ajar atau bahan ajar kimia bahan makanan adalah materi yang telah digunakan sebagai bahan ajar kimia bahan makanan sejak tahun 2012. Jadi yang dimaksud dengan bahan ajar berbasis web adalah bahan ajar hasil pengembangan dengan memanfaatkan teknologi komputer dan internet. Penggunaannya pun memerlukan perangkat komputer yang terkoneksi dengan internet. Kendala atau masalah yang dihadapi adalah: a. belum optimalnya pemanfaatan komputer di program studi Pendidikan Kimia, masih terbatas jumlah perangkat yang tersedia; b. Jaringan internet belum memadai untuk akses di kelas pembelajaran. Penelitian dan pengembangan ini dilaksanakan dengan mengacu pada tahapan penelitian dan pengembangan menurut Borg \& Gall. Borg \& Gall (2003) memaparkan ada sepuluh tahap dalam penelitian dan pengembangan, namun dalam penelitian dan pengembangan ini kesepuluh langkah tersebut disederhanakan menjadi tiga langkah. Adapun faktor-faktor yang mendasari penyederhaan tersebut yaitu:

1. Keterbatasan waktu

Jika penelitian dan pengembangan ini dilakukan dengan sepuluh tahapan akan memerlukan waktu dan proses yang relatif lama. Oleh karena itu, melalui penyederhanaan menjadi tiga tahapan penelitian dan pengembangan ini selesai dengan waktu yang lebih singkat tetapi tetap efisien dan efektif dalam proses dan hasilnya.

2. Keterbatasan biaya

Biaya yang relatif besar akan diperlukan jika penelitian ini dilakukan dalam sepuluh tahap. Oleh karena itu, melalui penyederhanaan tahapan penelitian ini bisa selesai dengan jumlah biaya yang relatif terjangkau.

3. Kesamaan tahapan 
Berdasarkan kesepuluh tahap penelitian dan pengembangan model Borg \& Gall, ada beberapa tahap yang memiliki kesamaan tujuan. Kesamaan tersebut terlihat pada beberapa tahap, seperti tahap ujicoba lapangan awal (preliminary field testing), tahap ujicoba lapangan (main field testing), dan tahap ujicoba pelaksanaan lapangan (operational field testing). Adanya kesamaan pada beberapa tahap ujicoba tersebut. Penelitian ini baru satu tahap ujicoba yaitu uji coba terbatas.

4. Pendapat Borg \& Gall Borg \& Gall (2003) menyarankan untuk membatasi penelitian dan pengembangan dalam skala kecil termasuk membatasi langkah penelitian.

Ketiga tahap penelitian dan pengembangan ini meliputi: a. tahap define yaitu pengumpulan informasi; $b$. Tahap design yaitu tahap perencanaan dan c. tahap develop yaitu tahap pengembangan, validasi dan ujicoba.

Tahap pengumpulan informasi dilakukan tinjauan studi pustaka. Setelah tahap pengumpulan informasi selesai, selajutnya dilakukan tahap perencanaan. Pada tahap ini dilakukan pembuatan kisi-kisi instrumen penelitian dan pembuatan instrumen penelitian. Kisi-kisi instrumen penelitian dibuat dengan berpedoman pada kriteria mengevaluasi media pembelajaran menurut Walker dan Hess. Kriteria penilaian media menurut Walker dan Hess menjadi pedoman dalam pembuatan kisi-kisi instrumen lembar validasi, dan angket respon siswa. Kisi-kisi instrumen yang telah selesai dibuat selanjutnya menjadi pedoman dalam pembuatan instrumen penilaian. Selanjutnya, tahap pengembangan produk terdiri dari pembuatan email dan alamat blog, penginstalan template dan fitur, penulisan materi, dan penambahan efek suara video, animasi dan gambar yang dibutuhkan. Setelah pengembangan produk selesai, maka diperoleh media pembelajaran interaktif berbasis web yang harus didukung dengan komputer dan internet.

\section{SIMPULAN}

Bahan ajar kimia bahan makanan berbasis web berupa website pembelajaran dengan alamat www.kimia-kesehatan.blogspot.co.id hasil penelitian dan pengembangan di Program Stdui Pendidikan Kimia FKIP Universitas Palangka Raya layak digunakan.

\section{SARAN}

Bahan ajar kimia bahan makanan berbasis web yang telah dihasilkan belum dilakukan ujicoba skala diperluas. Penelitian dan pengembangan lebih lanjut dapat dilakukan ujicoba skala diperluas dan diseminasi.

\section{DAFTAR PUSTAKA}

Ali, M. (2009). Pengembangan media pembelajaran interaktif mata kuliah medan elektromagnetik. Jurnal edukasi elektro. Vol.5, No.1. Maret. hlm11-18

Borg, W.,R., Gall, J.,P., Gall, M.,D. (2003). Education research: an introduction. USA: Pearson Education.

Hannafin, M.J., Janette, R.H. (1997). Cognitive strategies and learning from the world wide web. Educational Technology, Research and Development. ProQuest Education Journals. p.37

Nopriawan, B.A. (2016). Implementasi E-Learning Pada Pembelajaran Sains Di Sekolah Menggunakan Teknologi Acceptance Model (TAM) Dalam Inovasi 
Pendidikan. Jurnal Pendidikan Tekonologi dan Kejuruan Balanga, Volume 4, Nomor 1, Januari-Juni 2016, hlm. 40-47

Sukarna, I.M., Irawan, R. (2016). Pengembangan media pembelajaran kimia sma/ma berbasisandroid dengan mobile learning pada materi konfigurasi elektron dan tabel periodik unsur. eprints.uny.ac.id/42343/1/JURNAL.pdf. diunduh tanggal 8 Juni 2017.

Traxler, J. (2010). Students and mobile divices. ALT-Research in Learning Technology. Vol.18 No.2. July. p149-160. ISSN 0968-7769 